\title{
The Border Difference:
}

The Anishinaabeg, Benevolence, and State Indigenous Policy in the Nineteenth-Century Great Lakes Basin

\author{
Susan E. Gray \\ Arizona State University
}

\begin{abstract}
After the War of 1812, British and American authorities attempted to sequester the Anishinaabeg - the Three Fires of the Ojibwes (Chippewas), Odawas (Ottawas), and Boodewadamiis (Potawatomis)-on one side of the Canada-US border or the other. The politics of the international border thus intersected with evolving federal/state and imperial/provincial Native American/First Nations policies and practices. American officials pursued land cessions through treaties followed by removals of Indigenous peoples west of the Mississippi. Their British counterparts also strove to clear Upper Canada (Ontario) of Indigenous title, but instead of removal from the province attempted to concentrate the Anishinaabeg on Manitoulin and other smaller islands in northern Lake Huron. Most affected by these policies were the Odawas, whose homeland was bisected by the international border. Their responses included two colonies underwritten by missionary and government support, one in Michigan and the other on Manitoulin Island, led by members of the same family intent on providing land and educational opportunities for their people. There were real, if subtle, differences, however, in the languages of resistance and networks of potential white allies then available to Indigenous people in Canada and the US. The career trajectories and writings of two cousins, sons of the brothers who helped to craft the Odawa cross-border undertaking exemplify these cross-border differences.
\end{abstract}

Keywords: Canada-US borderlands, Anishinaabeg, state Indigenous policy, citizenship, landownership 
After the War of 1812, British and American authorities undertook systematic measures to sequester the Anishinaabeg - the "Three Fires" of the Ojibwes (Chippewas), Odawas (Ottawas), and Boodewadamiis (Potawatomis) - who were accustomed to moving freely throughout the Great Lakes region, on either side of the newly surveyed Canada-US border. ${ }^{1}$ The politics of the international border thus intersected with evolving federal/state and imperial/provincial Native American/First Nations policies and practices. On the US side of the border, officials pursued land cessions through treaties followed by removals of Indigenous peoples west of the Mississippi River. British officials also strove to clear Upper Canada (Ontario) of Indigenous title, but instead of removal from the province attempted to concentrate the Anishinaabeg on Manitoulin Island in northern Lake Huron and on smaller islands in Georgian Bay. These intersections of state policies and international politics forced the Anishinaabeg radically to reconfigure their own geopolitics - to choose Canada or the United States, and to determine how they might live surrounded by white settlement. None faced this dilemma more directly than the Odawas, whose homeland, which ranged in an arc from the eastern shore of northern Lake Michigan to Manitoulin Island and south from there to Walpole Island (Bkejwanong, "Place Where the Water Divides") in the Detroit River, had been bisected by the new international border.

It goes almost without saying that the Odawas did not accept this border. The human geography of their homeland was a vast web of kinship ties created by intermarriages among bands, the fundamental social unit of the

1 United by language, culture, and kinship, Ojibwes, Odawas, and Boodewadamiis have for centuries considered themselves one people, the Anishinaabeg, and they have overlapping tribal histories. Each nation, however, has also been shaped by distinct geopolitical circumstances. It should be noted that there is no standard orthography for Anishinaabemowin, the language of the Anishinaabeg. For clarity, I have indicated variant spellings for some of the names that appear in this essay, but in general I have relied on the most prevalent spellings in use today. On the Three Fires, see Phil Belfy, Three Fires Unity: The Anishinaabeg of the Huron Borderlands (Lincoln: University of Nebraska Press, 2011); James A. Clifton, et al., People of the Three Fires: The Ottawa, Potawatomi, and Ojibway of Michigan (Grand Rapids: Michigan Indian Press, Grand Rapids Inter-Tribal Council, 1986). Indispensable as overviews of Native Great Lakes history are Charles E. Cleland, Rites of Conquest: The History and Culture of Michigan Native Americans (Ann Arbor: University of Michigan Press, 1992); Helen Hornbeck Tanner, ed., Atlas of Great Lakes Indian History (Norman: University of Oklahoma Press, 1987). The two best works on Great Lakes Indians before 1815 are Michael A. McDonnell, Masters of Empire: Great Lakes Indians and the Making of America (New York: Hill and Wang, 2015) and Richard White's classic account, The Middle Ground: Indians, Empires, and Republics in the Great Lakes Region, 1650-1815 (Cambridge: Cambridge University Press, 2006 [1991]). 
Anishinaabeg. Undergirding this web was a clan system (doodemag) that organized families within bands, and ensured that individuals did not marry within their doodem. Thus, lateral kin such as cousins or brothers and sisters bound people together both within and across bands, while lineal ties, particularly for fathers and sons, established political authority. Bands expanded and contracted in size as they moved seasonally across designated areas of the homeland to plant and gather, fish, hunt, and make maple sugar. One of the most important duties of ogimaag, or headmen, was the apportionment of access to resources. ${ }^{2}$

This essay examines two kin-based Odawa responses to the intersections of state policies and international politics. It explores, first, two experimental colonies underwritten by missionary and government support at Manitowaning on Manitoulin Island and at Old Wing, near present-day Holland, Michigan. These colonies were led by members of the same Odawa family, who shared similar opinions about the need to establish colonies offering land ownership and educational opportunities, but who cast their lots on opposite sides of the international border as part of a trans-border Odawa policy of trying to preserve as much of their homeland as possible by dividing villages and families. Despite many similarities between Manitowaning and Old Wing, this strategy played out differently in Michigan and Upper Canada because of subtle, but real, differences in the languages of resistance and networks of potential allies, missionaries, and settlers available to Indigenous peoples in this period in Canada and the US. The career trajectories of two Odawa cousins of the family who played such large roles at Manitowaning and Old Wing help to flesh out these differences. Francis Assikinack (1824-1863), born on Manitoulin Island, and Andrew J. Blackbird (1820-1908), born in Detroit, were the sons of brothers who helped to craft the Odawa trans-border policy. The cousins' life experiences serve as testaments to what Walter Mignolo has called the "border difference"the ways that newly imposed geopolitical and internal colonial boundaries did - and did not - matter to Indigenous peoples. ${ }^{3}$

2 Heidi Bohaker, "Nindoodemag': The Significance of Algonquian Kinship Networks in the Eastern Great Lakes Region, 1600-1701," William \& Mary Quarterly, 63, no. 1: 23-52; Michael Witgen, An Infinity of Nations: How the Native New World Shaped Early North America (Philadephia: University of Pennsylvania Press, 2012), 29-68.

3 Walter Mignolo, Local Histories/Global Designs: Coloniality, Subaltern Knowledges, and Border Thinking (Princeton: University of Princeton Press, 2000). 
The story begins with a pivotal moment in the history of the Canada-US border for the Odawas. On March 28, 1836, a delegation of Odawa and Ojibwe ogimaag signed the Treaty of Washington, ceding to the federal government the western half of the Lower Peninsula of Michigan north of the Grand River and roughly half of the Upper Peninsula east of the Chocolate River. Although formally acceding to a massive transfer of real estate, the Anishinaabeg delegates had nevertheless managed to retain ownership of a substantial portion of their homeland in Michigan, and they had made no concessions to the federal policy of removal. Article 4 of the treaty set aside large, permanent reserves in the cession for Odawas and Ojibwes in both peninsulas, including 50,000 acres at Wawgawnawkezee (L'Arbre Croche), the heart of the Odawa homeland in northwestern Lower Michigan. ${ }^{4}$ Article 13 allowed the Anishinaabeg use-rights to the rest of the cession "until the land is required for settlement." Of removal, the treaty said only, in Article 8, that the federal government would mount an exploratory party to find a new, permanent home for the Odawas and Ojibwes somewhere southwest of the Missouri River "as soon as the said Indians wish it." In addition, the treaty promised annual annuities for twenty years, to be paid to the Anishinaabeg in severalty. The same article set aside funds for schools, missions, and agricultural implements, making clear Anishinaabeg determination to adjust to life amid white settlers while remaining on their own land in Michigan. ${ }^{5}$

The Anishinaabeg delegates, however, had not reckoned on the interference of the U.S. Senate, which in late May altered one of the central provisions of the Treaty of Washington before ratifying it. Instead of the permanent reserves originally agreed upon, Article 3 now set aside the designated tracts for "the term of five years (...) and no longer, unless the United States shall grant (...) permission to remain (...) for a longer period.” This critical change now made explicit and likely what had been implied and contingent in the March version of the treaty, and it left the Michigan Acting Superintendent of Indian Affairs, Henry Rowe Schoolcraft, who had negotiated

4 Odawa villages ranged south from the Straits of Mackinac to the Grand River Valley, with the greatest concentrations of population at Wawgawnawkezee and in the Grand River Valley (Owashshinong). See Tanner, ed., Atlas of Great Lakes Indian History, Map 24, 131.

5 "Treaty with the Ottawa, etc., 1836," in Charles J. Kappler, ed., Indian Treaties, 1778-1883, vol. II (Washington, DC: Government Printing Office, 1904), 450-56. The fullest account of the 1836 Treaty of Washington is Charles E. Cleland, Faith in Paper: The Ethnohistory and Litigation of Upper Great Lakes Indian Treaties (Ann Arbor: University of Michigan Press, 2011), 49-87. 
the treaty with the Anishinaabeg, the unlovely task of persuading them to agree a second time to the sale of their lands on considerably less favorable terms. This Schoolcraft undertook to do in early July at a meeting with Odawa and Ojibwe ogimaag on Mackinac Island. By July 18, he was able to report to Secretary of War Lewis Cass that he had finessed the Senate's change to the treaty by arguing to the Indians that Article 13, which allowed the Anishinaabeg hunting, fishing, and occupancy rights in the cession until it was "required for settlement," compensated for the loss of the permanent reserves. ${ }^{6}$

The next month, many of the same headmen who had met with Schoolcraft on Mackinac Island, some of them signatories of the Treaty of Washington, left in their canoes for Manitoulin Island, or Odaawa-Minis (Island of the Odawa) at the mouth of Georgian Bay in northern Lake Huron. There they expected to receive presents from, and to renew their alliance with, the British, an alliance dating from the 1764 Treaty of Niagara, upheld during the War of 1812, and still a powerful force in shaping British relations with the Anishinaabeg and other Great Lakes Indigenous peoples. There was nothing new about this journey from Wawgawnawkezee to Manitoulin Island. Since 1815, there had been a good deal of cross-border traffic by the Anishinaabeg as they attempted to play British and American authorities off against one another. Odawas at Wawgawnawkezee had discussed relocation to Manitoulin, and some, such as the ogima Jean-Baptiste Assiginack, had already done so. But it was not until the meeting on Manitoulin with British officials in August of 1836 that the island became a geopolitical alternative to remaining in the American-held portion of the Odawa homeland.

The British delegation arrived at the meeting intending to inform the Indians that their annual presents would be discontinued after five years, a shift in policy at odds with their historic alliance with the Anishinaabeg, and made in direct response to the US Senate's limitation to the same period of the Michigan reserves created under the Treaty of Washington. At the end of five years, colonial officials on both sides of the border believed, the Anishinaabeg would either be forced west by American policy or east by British policy. Shocked by this announcement, Assiginack produced the "Two Row Wampum" belts given by the British to twenty-four Indigenous nations at Niagara in 1764. These belts symbolized the Crown's "commit- 
ment to the peaceful and respectful relations with the Indigenous peoples represented there." 7 So forceful was Assiginack's reminder to the British of their promises that Sir Francis Bond Head, the Lieutenant-Governor of Upper Canada, shifted policy again on the spot. He declared that Manitoulin and the 23,000 other islands in Georgian Bay would be set aside as a single reserve for the Anishinaabeg. From the British perspective, the treaty then compacted was a way of concentrating the Indigenous population of Upper Canada in an area of the province remote from white settlement. From an Anishinaabeg perspective, the treaty conferred the permanent homeland that the delegates thought they had successfully negotiated in the Treaty of Washington earlier in the year.

Following this second, Canadian, treaty of 1836, many Anishinaabeg did relocate on Manitoulin, but the island did not thereby become a refugee camp, although some Boodewadamiis from the US did take refuge there to evade federal removal. The choice between Canada and the United States was neither simple nor obvious. Odawas at Wawgawnawkezee and on Manitoulin took full advantage of the Uprisings in Canada in the late 1830s, rebellions directed against authoritarian colonial rule that were greatly encouraged by American filibustering, to bargain with their political loyalty. As Alan Corbiere has argued, the important point is to view this bargaining from the perspective of Anishinaabeg self-interest, an understanding of which only emerges by bringing together the archival records from both sides of the border. Read independently, the national documents indicate that Odawas in Michigan or Upper Canada were concerned only with retaining their lands in those places. Read together, the documents point to a trans-border Odawa policy of trying to preserve as much of the entire homeland as possible by dividing villages and families between Manitoulin and Michigan and dealing with both colonial powers at the same time. ${ }^{8}$

7 Michael Coyle, “As Long as the Sun Shines: Recognizing That Treaties Were Intended to Last," in Michael Coyle and John Borrows, eds., The Right Relationship: Reimagining the Implementation of Historical Treaties (Toronto: University of Toronto Press, 2017), 49.

8 Alan Corbiere, "Mookomaanish: The Damned Knife," in Alan Corbiere, Deborah McGregor, and Crystal Migwans, eds. Anishinaabewin Niswi: Deep Roots, New Growth. Proceedings of the 2012 Anishinaabewin Niswi Multidisciplinary Culture Conference (M'Chigeeng, ON: Ojibwe Cultural Foundation, 2013). See also Cecil King, Balancing Two Worlds: Jean-Baptiste Assiginack and the Odawa Nation (Saskatoon: Dr. Cecil King, 2013), 205-56. Most accounts of the 1836 Manitoulin Treaty focus on Bond Head's shift in Indian policy for Upper Canada away from civilization to isolation, and emphasize the resistance of Saugeens and other Ojibwes to giving up their land in exchange for relocation on the less-than-fertile islands of Georgian Bay. This interpretation is correct as far as it goes, but it does not consider the position of Odawas 
This trans-border policy, however, did not play out on the ground in Michigan and on Manitoulin in exactly the same way. National geopolitics and local circumstances mattered. As Roger Nichols has argued, despite the many parallels and overlaps in time between Canadian and American Indian policies and their implementation, a signal border difference is the American policy of removal, which has no Canadian counterpart. The concentration of Indigenous population on Manitoulin Island that Sir Francis Bond Head had in mind in 1836 was hardly the equivalent of Andrew Jackson's ambition to relocate all Indians in the eastern US west of the Mississippi River. ${ }^{9}$

Nichols's contention about removal policy as a key marker of difference between Canadian First Nations and American Indian policies requires some qualification in light of John Bowes's recent reconsideration of removal in the northern United States, which proceeded differently from the Cherokee Removal, the sine qua non of the political and constitutional controversy that swirled around implementation of the 1830 Removal Act. Removal in the North was incomplete, Bowes explains, where settlers did not press state officials for it, and it occurred piecemeal in accordance with what Patrick Wolfe has characterized as the "logic of elimination." Seen in this way, removal construed broadly as an inexorable process of displacement was foundational to settler colonialism, in evidence in British North America in the earliest relations between colonists and Indigenous people..$^{10}$

Bowe does not extend his argument about removal north of the border to Canada. If he had, his own case would have required some modification, such as the sheer lack of settler demand for Indigenous lands in the seventeenth and eighteenth centuries, and the slowness of settler advance in the early decades of the nineteenth century. In Upper Canada, British officials only slowly made purchases of Indigenous land for settlers, and they made no provision for the natives' displacement. ${ }^{11}$ Moreover, there is no Ameri-

for whom Manitoulin Island was the center of their homeland. See, for example, Roger Nichols, Indians in the United States and Canada: A Comparative History (Lincoln: University of Nebraska Press, 1998), 190-94.

9 Nichols, Indians in the United States and Canada, 178-84.

10 Patrick Wolfe, "Against the Intentional Fallacy: Egocentricism and Continuity in the Rhetoric of Indian Dispossession," American Indian Culture and Research Journal, 36, no. 1 (2012): 3-45; John P. Bowes, Land Too Good for Indians: Northern Indian Removal (Norman: University of Oklahoma Press, 2016).

11 Robert J. Surtees, "Land Cessions, 1763-1830," in Edward S. Rogers and Donald B. Smith, eds., Aboriginal Ontario: Historical Perspectives on First Nations (Toronto: Dundurn Press, 1994), 107-11. 
can equivalent of the Treaty of Niagara, which bound the parties to share land and resources, and was in part intended to warn American colonists against encroaching on Indian Country. Although observed frequently in the breach, the principle of sharing the land remained formally part of Canadian Indian policy until 1930.

The 1836 Manitoulin Treaty thus represented a different moment in time in the history of relations between the Crown and the Anishinaabeg than the 1836 Treaty of Washington did for relations between the federal government and the Anishinaabeg. Bond Head's behavior initially reflected British perception that the Niagara alliance was not as useful as a weapon against American aggression as it had once been. His subsequent decision formally to designate Manitoulin Island as an Indian reserve at once inaugurated a policy of displacement in recognition of the advance north of settlement in Upper Canada, and demonstrated that the commitment made by the Crown at Niagara still had force on-the-ground. The Treaty of Washington, in contrast, promised the Anishinaabeg that they could continue to occupy their homelands only for as long as settlers did not covet them.

One of the ways in which Odawas fought the threat of removal posed by the Treaty of Washington was to appropriate for themselves the American rhetoric of citizenship and its deep association with ownership of property in land. Some of them saved their treaty annuity monies and, with the assistance of evangelical Protestant white settlers and missionaries, bought land and settled in colonies. One of these colonies, Old Wing Mission (named for an Odawa headman loyal to the Americans during the War of 1812), was the work of Ogemainne, a nephew of Mackadepenessay, who signed the Treaty of Washington, and Assiginack, who had been so instrumental in bringing about the Manitoulin treaty. These brothers of Old Wing had fought with the British during the War of 1812. Less than a month after the signing of the Treaty of Washington, Ogemainne, who was deeply skeptical even before Senate's intervention that the treaty had secured a permanent Odawa homeland, petitioned President Jackson and the U.S. Congress, asking that the treaty's provisions be reconsidered. ${ }^{12}$

He made his petition from Allegan, a newly established lumber town in southwestern Michigan, where he got help in composing his appeal; unable to write in English, Ogemainne signed the petition as "Joseph Wakazoo"

12 Joseph Wakazoo, "Petition to the President of the U.S. \& the Senate and the House of Representatives," April 29, 1836, NAM, RG75, MSMALR, M1, Roll 41. 
with his mark. ${ }^{13}$ Accompanying the petition were the signatures of sixtyeight Allegan citizens, attesting to the ogima's honorable character and praying that his request would receive a favorable hearing. That Ogemainne sought such support from white settlers shows, first, his well-developed understanding of the relationship between federal government and citizenry. ${ }^{14}$ Local alliances with American citizens potentially gave natives leverage in negotiating with the federal government that they, as tribal people, did not otherwise possess. Characterized by Chief Justice John Marshall in 1831 as "dependent domestic nation[s]," they were in the republic but not of it, neither collectively foreign powers nor individually citizens..$^{15}$ It is also significant that Ogemainne's petition came from Allegan, where the signatories were indeed settlers and not men implicated in the fur trade, as they would have been had Ogemainne circulated his petition at Mackinac, the only center of white population in the northern Lower Peninsula. The Allegan origins of the petition signaled to federal officials Ogemainne's desire to break with the older world of the fur trade and to make a new life amidst whites.

13 Joseph Wakazoo was Ogemainne's baptismal name; in taking "Wakazoo" as his surname, he followed a common practice among Anishinaabeg converts to Christianity in adopting their father's names. The name Wakazoo also appears in the records as Wakazo and Waukazoo, the latter spelling being the one most commonly used today. The elder Waukazoo was the brother of Makadepenessey and Assikinack.

14 As many scholars have recently shown, indigenous people's resistance to the pressures of settler colonialism were highly situational and could therefore take a variety of forms. Stephen Warren, for example, has analyzed a continuum of behavior on the part of nineteenth-century Shawnees ranging from flight to accommodation to violent opposition. Alexandra Harmon, Paige Raibmon, and Katrina Jagodinsky, among others, have demonstrated how, particularly in the early phases of white settlement, relations between indigenous peoples and newcomers could be mutually beneficial, involving exchanges of labor and resources and intermarriages. This essay falls generally within this interpretive framework of emphasizing indigenous agency. It is specifically focused, however, on the way that, in the context of the threat of federal removal, Odawas deployed the American language of citizenship to promote indigenous sovereignty, while pursuing quite a different strategy toward the same end on the other side of the Canada-US border. Stephen Warren, The Shawnees and Their Neighbors, 1795-1870 (Urbana: University of Illinois Press, 2009); Alexandra Harmon, Indians in the Making: Ethnic Relations and Indian Identities around Puget Sound (Berkeley: University of California Press, 1998); Paige Raibmon, Authentic Indians: Episodes of Encounter from the Late-Nineteenth-Century Northwest Coast (Durham, NC: Duke University Press, 2005); Katrina Jagodinsky, Legal Codes and Talking Trees: Indigenous Women's Sovereignty in the Sonoran and Puget Sound Borderlands, 1854-1946 (New Haven: Yale University Press, 2016). For a provocative account of the historical complexity of indigenous peoples' relationship to American citizenship, see Joanne Barker, Native Acts: Law, Recognition, and Cultural Authenticity (Durham, NC: Duke University Press, 2011). See also David E. Wilkins and K. Tsianina Lomawaima, Uneven Ground: American Indian Sovereignty and Federal Law (Norman: University of Oklahoma Press, 2001).

15 Cherokee Nation v. State of Georgia, 30 U.S. Supreme Court 1831. caselaw.findlaw/US-supremecourt/30/1.html 
In the petition, Ogemainne/Wakazoo first establishes his credentials as an ogima with "about fifty families" "under my care." Praising American laws as "wise and good," he asks that he and his people be brought under their jurisdiction as citizens. The reserves granted to the Anishinaabeg under the Treaty of Washington he sees as no guarantor of Indian rights: "we do not wish to make reservations of the land for ourselves, which we shall be obliged to sell at some future time whether we wish it or not." Citizenship, as Wakazoo understood it, rested on property in land represented by deeds bearing the "Presidents patent" that would be upheld in "courts of Justice" and not subject, like Indian reservations, to the vagaries of federal dictate. Instead of a reservation, would the federal government not deed to Wakazoo and his band "some land from which has been bought of the Indians"? As landholders, Wakazoo and his people wished to join with other Allegan citizens in creating the landscape of settlement, a form of being on the land evoked by Wakazoo in his petition. The Odawas wanted "Schools, Churches, \& Roads," and they wanted their land to be subject to taxation as proof of their commitment to the project. Should his petition be granted, Wakazoo concludes, "the poor Indian will at last feel that he has a home, $\&$ that he may lay his bones where he will feel that the bones of his descendants for ages to come will be." This statement artfully evokes Hugh Brody's powerful observation that while Indigenous hunting societies have long been considered mere nomads without any claim to the land that acquisitive whites needed to respect, European and neo-European settlers have been ever ready to move and move again. ${ }^{16}$ Wakazoo depicts himself and his people as wanderers seeking, through the alchemy of property, to become settlers, when in fact they seek to remain in a home they have long occupied.

Wakazoo's petition faced squarely the dilemma of Indigenous people trying to translate their claim to their homeland resting on prior occupancy to one based on property ownership. From a settler-colonial point of view, seasonal mobility around a homeland, no matter how long-standing and how well understood its territorial borders, did not prove ownership. On the

16 Hugh Brody, Maps \& Dreams: Indians and the British Columbia Frontier (Prospect Heights, IL: Waveland Press, 1981). Helpful in making the link between Brody's and Wakazoo's arguments was Brenda Macdougall, Carolyn Podruchny, and Nicole St-Onge, "Introduction: Cultural Mobility and the Contours of Difference," in Nicole St-Onge, Carolyn Podruchny, and Brenda Macdougall, eds., Contours of a People: Metis Family, Mobility, and History (Norman: University of Oklahoma Press, 2012), 3-21. 
contrary, Indigenous mobility offered prima facie evidence of impermanence and undermined any claim to territory. Only property, owned in fee simple, provided proof of civilized land-use. Settler "improvement" of land for the agriculture also attested to civilized land-use, despite the fact that in many instances standards of cultivation differed little between Indigenous people and white settlers.

Ogemainne and whoever helped him to draft the petition may well have known that the logic of his appeal turned on its head Andrew Jackson's declaration six years earlier in defense of the Removal Bill that, "painful" as it would be for Indians "to leave the grave of their forefathers," they would be doing nothing more than what white Americans had always done. " 17 "And is it to be supposed," he averred, "that the wandering savage has a stronger attachment to his home than the settled, civilized Christian"? But Jackson's callous dismissal of Indigenous land claims was also weirdly truthful: to settle for white Americans did not mean to establish binding ties to a home. Hence the double paradox posed by Wakazoo's petition: that people accused of being essentially homeless would adopt practices their detractors associated with permanence to defend long-established homes, while their detractors engaged in those same practices continually to remake their homes in new locations.

Ogemainne received no federal response to his petition but, undeterred, he and his band, with the assistance of settler-allies, pursued their plan to perform as citizens, buying land with their treaty-annuity monies, breaking roads, paying taxes, and securing the services of a Congregational missionary to teach and preach. They were not alone in their endeavors. Two other Odawa bands bought land in the late 1830s in southern Michigan with the assistance of white evangelical settlers and missionaries..$^{18}$ All three of these initiatives had failed by 1850 , swallowed up in the rush of white settlers disinclined to honor Indigenous property rights. In 1849, Old Wing Mission moved north to the Leelanau Peninsula, north and west of present-day Traverse City. There Ogemainne's band, now led by his brother Peter Waukazoo (Pendunwan), joined other Anishinaabeg, who had been buying land around Grand Traverse Bay and on the peninsula as soon federal surveying

17 Andrew Jackson, "State of the Union Address," December 6, 1830. https:www.ourdocuments.gov/doc.php?doc=25\&page=transcript.

18 Susan E. Gray, "Limits and Possibilities: White-Indian Relations in Western Michigan in the Era of Removal," Michigan Historical Review 20 (Fall 1994): 71-92. 
was completed in the late 1840s. By 1855 , Indigenous people owned fully a third of all land alienated on the Leelanau.

Examples of Indigenous property ownership as a way of evading the federal program of removal were not limited to Odawas or to Michigan. As James J. Buss has shown, the Wyandot decision to buy land in Ohio resulted from consultation with Haudenosaunee people themselves engaged in a rear-guard action, to save what they could of their historic homeland. Buss has also convincingly reinterpreted the land purchases in Indiana of the Miami chief Jean Baptiste Richardville, once interpreted as evidence of personal greed and corruption, as the means of saving at least some of his people from removal by settling them on his property. These cases in Michigan, Indiana, and Ohio, as well as that documented by C. Joseph GenetinPilawa for the Buffalo Creek Seneca, and as I have shown for Old Wing Mission, entailed elaborate trans-local networks allying Native people with settlers, various representatives of the Benevolent Empire - the evangelical network of churches, missionary societies, periodicals, and publishing houses, as well as state and federal officials. ${ }^{19}$

There are many resemblances between Old Wing Mission and Manitowaning, the Anglican-run mission established on Manitoulin by the Indian Office in the wake of the 1836 treaty. These can be seen in the program of civilization that Protestant missionaries and government officials attempted to impose, in the Indians' refusal to abandon their seasonal round and remain full-time on their farms, and in the religious conflict between Protestant and Catholic converts, contributing in the case of Old Wing to the Leelanau Peninsula in 1849. In Canada, conflict between Protestant Manitowaning and the nearby Catholic community of Wikwemikong ultimately resulted in the failure of Manitowaning, while Wikwemikong residents succeeded in saving the eastern end of the island from allotment and opening to white settlement along with the rest of Manitoulin in $1862 .{ }^{20}$ All this is true

19 James J. Buss, Winning the West with Words: Language and Conquest in the Lower Great Lakes (Norman: University of Oklahoma Press, 2011), 73-95; Idem, "Imagined World and Archival Realities: The Patchwork World of Early Nineteenth-Century Indiana," in C. Joseph Genetin-Pilawa and James J. Buss, eds., Beyond Two Worlds: Critical Conversations on Language and Power in Native North America (Albany: SUNY Press, 2014), 97-116; C. Joseph Genetin-Pilawa, Crooked Paths to Allotment: The Fight over Federal Indian Policy after the Civil War (Chapel Hill: University of North Carolina Press, 2012), 13-50; Susan E. Gray, Lines of Descent: Family Stories from the North Country (Chapel Hill: University of North Carolina Press, forthcoming), Chapters 1 and 5.

20 On Manitowaning, see Ruth Bleasdale, "Manitowaning: An Experiment in Indian Settlement," Ontario 
enough. But the point here is not the obvious one about missionary-particularly Protestant -ineptitude knowing no borders. The point, instead, is the border difference: Indigenous appropriation of the Christian republican rhetoric on the US side of the border, at Old Wing and elsewhere, has no Canadian equivalent.

These cross-border differences raise several issues worthy of further study. One is the relationship between property in land and citizenship in nineteenth-century Canada and the United States. In both countries, male ownership of land was unquestionably a desideratum of the liberal state, as the passage of remarkably similar American and Canadian Homestead Acts ten years apart makes clear. ${ }^{21}$ Nevertheless, the notion of ownership of land as fundamental to a nation of self-governing citizens did not carry in Canada the ideological charge that it did in the United States, there being no such thing as Jeffersonian republicanism north of the border. And British authorities in the decades after 1815 strove to ensure that there would not be. Unrest in the Canadas over limited access to land and thwarted claims to self-rule ultimately led to the Uprisings of 1837-38 and the call for "responsible government," the first step toward Confederation in 1867. Throughout this rocky period in Canadian history, British and Canadian officials consistently blamed, with some justice, American republican ideas and filibustering American republicans for manifestations of popular discontent with British rule. ${ }^{22}$

If republican rhetoric proved problematic for white subjects in Upper Canada in this period, how much more unlikely were Indigenous people to appropriate it for their own use? Moreover, American representatives in Canada of the Benevolent Empire were also deemed carriers of republican

History, LXVI (1974): 147-57; Robert J. Surtees, "The Development of an Indian Reserve Policy in Canada," Ontario History, 61, no. 2 (1969): 87-98; Mrs. [Anna] Jameson, Winter Studies and Summer Rambles in Canada, vol. II (New York: Wiley and Putnam, 1839), 281-92.

21 Sheila McManus, The Line Which Separates: Race, Gender, and the Making of the Alberta-Montana Borderlands (Lincoln: University of Nebraska Press, 2005), 37-41. The signal difference in homestead provisions between the two countries was the Canadian refusal to allow single women to file claims, a restriction which did not obtain in the US. See Sarah Carter, Imperial Plots: Women, Land, and the Spadework of British Colonialism on the Canadian Prairies (Winnipeg: University of Manitoba Press, 2016), 38-84.

22 Albert B. Corey, The Crisis of 1832-42 in Canadian-American Relations (New Haven: Yale University Press, 1941); Fred Landon, Western Ontario and the American Frontier (Toronto: Ryerson Press, 1941); Colin Read, The Rising in Western Upper Canada, 1837-8: The Duncombe Revolt and After (Toronto: University of Toronto Press, 1982); Carol Wilton, Popular Politics and Political Culture in Upper Canada, 1800-1850 (Montreal: McGill-Queens University Press, 2000). 
contagion. In the name of Christian loyalism, for example, British Wesleyan Methodists in the years before the Uprisings largely drove American Methodist clergymen from Upper Canada. In other words, not only did the potential languages of resistance available to Indigenous people differ in this period in the United States and Canada, but so did the networks of potential allies. ${ }^{23}$ To see how and why this was the case requires a shift in focus from Ogemainne and other Michigan Odawas' strategy of buying land and pursuing citizenship to the career trajectories of Ogemainne's cousins, Andrew J. Blackbird, son of Mackadepenessay, and Francis Assikinack, son of Jean Baptiste Assiginack, and their often-fraught engagement with organized benevolence in relation to state Indigenous policies as implemented in Canada and the United States.

These trajectories are best understood over several generations of family history and the changes in the geopolitics of the northern Great Lakes in the late eighteenth and early nineteenth centuries. The best single source for this family history is Andrew J. Blackbird's History of the Ottawa and Chippewa Indians of Michigan (1887), in which he traces the ogimaag in his family back to Pontiac's War in 1763, the impetus for British renewal of their alliance with the Anishinaabeg and other Indigenous peoples the following year in the Treaty of Niagara. Blackbird's father, Mackadepenessay, as well as his grandfather and great grandfather, all served as ogimaag. In referring to this status as "the first royal rank among the Ottawa, Blackbird signals in his History that the status of ogimaag was frequently hereditary in this society organized by patrilineal descent. As Cary Miller has explained, however, ogimaag lacked coercive power; they demonstrated their worthiness to lead through successful performance of their responsibilities for their bands. ${ }^{24}$

23 Christopher Adamson, "God's Continent Divided: Politics and Religion in Upper Canada and the Northern and Western United States, 1775 to 1841," Comparative Studies in Society and History, 36, no. 3 (July 1994): 417-46; Edward S. Rogers, "The Algonquian Farmers of Southern Ontario, 1830-1945," in Edward S. Rogers and Donald B. Smith, eds., Aboriginal Ontario: Historical Perspectives on the First Nations (Toronto: Ontario Historical Studies Series for the Government of Ontario, Dundurn Press, 1994), 12266. Donald B. Smith's Mississauga Portraits: Ojibwe Voices from Nineteenth-Century Canada (Toronto: University of Toronto Press, 2013) is highly suggestive of trans-border evangelical linkages involving Indigenous people without developing the point. A work that compares trans-border missionary attitudes and missionizing is C. L. Higham, Noble, Wretched \& Redeemable: Protestant Missionaries to the Indians in Canada and the United States, 1820-1900 (Albuquerque: University of New Mexico Press, 2000). This work, however, is focused on western Canada and the United States and on missionaries as a group, not on networks of benevolence and their relation to the state.

24 Andrew J. Blackbird, History of the Ottawa and Chippewa Indians of Michigan; A Grammar of Their Lan- 
In this cross-border story, discussion of the generation of Andrew $\mathrm{J}$. Blackbird's and Francis Assikinacks' fathers is pivotal, but requires, first, a clarifying detour into Anishinaabe naming patterns and orthography. Francis Assikinack and his father, Jean-Baptiste Assiginack (also known as the "Blackbird") shared the same last name in Anishinaabemowin (Anishinaabe language), but with variant spellings in English transcription. Assiginack and Assikinack, for example are the spellings of the father's and son's names, respectively in the Dictionary of Canadian Biography. Assiginack is sometimes also rendered Assiginac, whereas Blackbird in his History refers to his uncle as "Au-se-go-nock." 25 According to his son, Mackadepennessay's name actually meant "Black Hawk," a reference to the family dodem, but "somehow it has been translated as Blackbird, so we now go by this latter name." 26

The generation of Mackadepennesay and Assiginack included a third brother germane to the cross-border story: Waukazoo, the father of Ogemainne (Joseph Wakazoo), the founder of Old Wing Mission. Beginning in the 1790s, the three ogimaag confronted the increasing American presence, followed by dominance in the Upper Great Lakes following the War of 1812. Waukazoo's response was to follow the fur trade to the Red River Country in Canada, where he died, probably not long after the War of 1812. Mackadepenessay and Assiginack, in contrast, fought together during the war on the side of the British. ${ }^{27}$ After the war, Mackadepenessay and other ogimaag at Wawgawnawkezee, the Odawa settlement in northwestern Lower Michigan, campaigned to obtain a Catholic missionary for their villages. Their initiative brought Assiginack, a Catholic who had once been a pupil at the Sulpician School at Lac-des-Deux Montagnes near Montreal, from Upper Canada to a new Catholic village at Wawgawnawkezee, where

guage and Personal and Family History of the Author (Ypsilanti, MI: The Ypsilantian Job Printing House, 1887 [reprint ed.: Little Traverse Regional History Society, n.d.]), 9; Cary Miller, Ogimaag: Anishinaabeg Leadership, 1760-1845 (Lincoln: University of Nebraska Press, 2010), 65-113.

25 Douglas Leighton, “Assiginack,” Dictionary of Canadian Biography, IX (1976): 8-10; Blackbird, History, 47.

26 Blackbird, History, 27.

27 John Tanner, The Falcon: A Narrative of the Captivity \& Adventures of John Tanner during Thirty Years Residence among the Indians of the Interior of North America (New York: Penguin Books, 1994 [1830]), 158-65; James McClurken, Gah-Baeh-Jhagwuh-Buk The Way It Happened: A Visual Culture History of the Little Traverse Bay Bands of Ottawa (East Lansing: Michigan State University museum, 1991), 6; J. Garth Taylor, "Assiginack's Canoe: Memories of Indian Warfare on the Great Lakes," The Beaver, 66, no. 5 (1986): 49-53. 
he served as catechist in the absence of a priest. The mission was not formally established until 1827, the school begun with it flourishing temporarily and then floundering for lack of diocesan support. ${ }^{28}$ Taking a number of families with him, Assiginack left Wawgawnawkezee in 1830 for Penetanguishene on the Bruce Peninsula in Upper Canada, where the British garrison had relocated from Drummond Island in 1828, and resumed his old work as an interpreter for the Indian Department. Then came 1836 and the Canadian treaty with the Anishinaabeg that set aside Manitoulin Island for Indigenous peoples and established Manitowaning as a model agricultural, Christian community. Assiginack moved to Manitoulin and cooperated closely with the northern superintendent of the Indian Department to make Manitowaning a success. ${ }^{29}$

Here the parallel careers of Blackbird and his cousin Assikinack suggest how border differences could play out in individual lives. We do not know, of course, what Assikinack would have made of his life had he lived into his eighties, as did his cousin, but several points stand out about their respective educations and early adulthood. The fathers of both men were convinced that education was the way forward for their children. Mackadepenessay, who invented an Odawa alphabet based on Roman orthography, sent an older son and daughter with their cousin away from Wawgawnawkezee for Catholic educations - the two boys all the way to Rome. Assiginack arranged for his son Francis to attend Upper Canada College in Toronto. After completing his college course, Francis tried to persuade the Indian Department to support his studying medicine, but was told that the cost would outweigh the benefit to the department. He was instead given a position as clerk and interpreter to the superintendent of the Indian Department in Toronto, and when he balked, saying he preferred to remain in school, was told that it was time for him to show some return on the government's investment. Unhappy as a clerk, Assikinack subsequently became the teacher at Wikwemikong, where he fought continually with Frederick

28 McClurken, Gah-Baeh-Jhgwah-Buk, 18-21; Idem, "'We Wish to Be Civilized': Ottawa-American Contexts on the Michigan Frontiers" (East Lansing: Michigan State University, Ph.D. diss., 1987), 1135-56; John Gilmary Shea, Catholic Missions among the Indian Tribes of the United States (New York: Arno Press \& The New York Times, 1969), 377-78, 383-91.

29 Douglas Leighton, "Francis Assikinack," Dictionary of Canadian Biography, IX (1976); King, Balancing Two Worlds; James Hamilton Cleland, The Georgian Bay: An Account of Its Position, Inhabitants, Mineral Interests, Fish, Timber, and Other Resources with Map and Illustrations (Toronto: James Baird \& Son, 1893), 63-99, passim. 
O'Meara, the missionary at Manitowaning. He was then reposted as head clerk of the Indian Department in Toronto, from which position he also worked as an interpreter in various treaty negotiations, including the 1862 treaty to open Manitoulin to white settlement, the year before his death. All in all, his was a short, unhappy life, made completely within the confines of the Indian Department. ${ }^{30}$

Blackbird's path to an education was far less straightforward and had its own frustrations. He was much younger than his Catholic siblings, and his father was very old when he left home to work as an assistant blacksmith at one of the Protestant missions established under a provision of the 1836 treaty. Protestant benefactors enabled him to study for several years at the Twinsburg Institute, a class-mate of his cousin Joseph Waukazoo (the son of Ogemainne) from Old Wing Mission, until his father's failing health forced him to return to Wawgawnawkezee. ${ }^{31}$ Several years later, determined like his Canadian cousin to become a doctor, he attempted to enroll at the University of Michigan, but could not obtain financial support for his studies. Instead, Lewis Cass, the former territorial governor of Michigan, steered him toward the Normal School in Ypsilanti. Blackbird then sought to become a teacher at a Protestant mission, but again could not find white backers for his ambitions. In 1862, he finally obtained steady government employment as an interpreter and later postmaster at Little Traverse. From this position, he would watch and protest the unfolding consequences of the 1855 Treaty of Detroit, which guaranteed the signatories of the 1836 treaty and their descendants permanent residence in Michigan, but at the price of individual allotments of land in place of the reserves for bands set aside in $1836 .{ }^{32}$ The preservation of Wikwemikong as an unallotted Odawa land base has no equivalent in the area of Michigan ceded by the Anishinaabeg in 1836 and, indeed, only one Anishinaabe reservation in the Upper Midwest today, Red Cliff in northwestern Wisconsin, was never subjected to allotment.

In letters to the Michigan Superintendent of Indian Affairs, the Reverend Samuel Bissell of the Twinsburg Institute, and others, Blackbird proved a

30 Leighton, "Francis Assikinack," 10-11; H. G. Tucker, "A Warrior of the Odahwahs," Ontario History XVIII (1920): 32-35; Cleland, The Georgian Bay, 63-99, passim.

31 George Nelson Smith, Annual Memoranda Books, 1840-46, 1848-49, entries for December 27, 1848, and January 20, 1849; George Nelson Smith to Samuel Bissell, November 17, 1851, MS 116, Container 1, Folder 2, Samuel Bissell Papers.

32 Cleland, Faith in Paper, 49-87. 
powerful witness to the federal ineptitude compounded by wholesale fraud and outright theft that drastically reduced the Anishinaabe land base in Michigan, the fiercely partisan local politics that repeatedly tested the limits of the state citizenship conferred on Michigan Indians in 1850, and the Civil War, which raised the specter of Indian "disloyalty." While participating in these events, sometimes at considerable risk of violence to himself, Blackbird strove in his writings to argue the case for Indigenous equality with whites on the basis of their shared citizenship as Americans. ${ }^{33}$ There is no equivalent of this local contest for Indigenous citizenship in Upper Canada.

There are some striking similarities in the lives and careers of Blackbird and his cousin Assikinack, and some equally forceful differences that cannot be explained by solely by individual temperament and circumstance. As sons of ogimaag, Assikinack and Blackbird could expect as adults to assume positions of leadership among their people. Fundamental to their fathers' shared vision for their sons' futures was education, and the ambitions that the young men ultimately conceived were not modest; the cousins sought to become doctors, and they intended to use their training in the service of their people. Frustrated in these ambitions, they then pursued alternate careers continually constrained by white racism and condescension. These constraints point to the border differences in the lives of Assikinack and Blackbird, and they mirror the larger differences in Canadian and US state policies and their implementation toward Indigenous people.

To his immense frustration, Francis Assikinack found his life and career controlled by the Indian Office. To British and Canadian officials, he was a subject, educated for service to the state. In contrast, Andrew Jackson Blackbird (as befit his name, although he later became a staunch Republican partisan) spent his life in search of white patronage, both within the Benevolent Empire and from local, state, and federal officials. It was not coincidental that he served both as a local postmaster, a federal patronage appointment for which white settlers vied, and as an interpreter for the Office of Indian

33 Susan E. Gray, "Performing Citizenship: Andrew J. Blackbird and the Politics of Anishinaabe Persistence, 1850-1887," American Indian Workshop, Zurich, April 12-15, 2012; Theodore J. Karamanski, Blackbird's Song: Andrew J. Blackbird and the Odawa People (East Lansing: Michigan State University Press, 2012), 145-66. On state citizenship for Michigan Indians, see Deborah Rosen, American Indians and State Law: Sovereignty, Race, and Citizenship, 1790-1880 (Lincoln: University of Nebraska Press, 2007), 131-36, 202-15. On allotment and the Indigenous land base, see William James Gribb, "The Grand Traverse Band's Land Base: A Cultural Historical Study of Land Transfer" (Lansing: Michigan State University Ph.D. diss., 1982). 
Affairs, the American equivalent of the Canadian Indian Department. Blackbird's career, in other words, ran the gamut of possible local employment opportunities afforded by the federal patronage system to settlers. Indeed, the hostility that he periodically encountered from his white neighbors derived in part from their covetousness. Blackbird also incurred settler ire by attempting to organize Anishinaabeg to vote Republican, an effort deeply resented by Democratic stalwarts used to buying Indigenous votes with alcohol. And Blackbird was not quiet about settler abuse of Anishinaabeg homestead claims, writing letter after letter to federal officials. In short, Blackbird spent his life performing citizenship, on his own behalf and that of his people.

Despite these differences, the cousins both found themselves witnesses to the struggle of the Anishinaabeg in northern Michigan and on Manitoulin Island to retain their land base. Blackbird's family placed its faith in deeds as proof of landownership and citizenship attesting to their equality with whites, yet these efforts could not withstand the determination of white Americans, who believed that land was theirs for the taking, and that Indigenous people had no rights that they were bound to respect. Assikinack's family put its faith in the resolve of British officials to uphold the obligation of the Two Row Wampum belt and to reserve Manitoulin Island in perpetuity for the Anishinaabeg. Yet in 1862, Assikinack was also a witness to his people's loss of their land base when much of Manitoulin was allotted and opened to white settlement - all except Wikwemikong, whose survival would have been unimaginable in Michigan.

\section{Bibliography}

\section{Unpublished Works:}

Gray, Susan E. Lines of Descent: Family Stories from the North Country. Forthcoming, University of North Carolina Press.

."Performing Citizenship: Andrew J. Blackbird and the Politics of Anishinaabe Persistence, 1850-1887," American Indian Workshop. Zurich. April 12-15, 2012.

Papers of Samuel Bissell. MS 116. Cleveland: Western Reserve Historical Society.

Records of the Michigan Superintendency of Indian Affairs and Mackinac Agency. Letters Received. January 3, 1835 to June 6, 1836. National Archives and Records Administration. Record Group 75. Microfilm 1. Roll 41.

Records of the Michigan Superintendency of Indian Affairs and Mackinac Agency. Letters Sent. July 18, 1836 to June 26, 1839. National Archives and Records Administration. Record Group 75. Microfilm 1. Roll 37.

Smith, George Nelson. Annual Memoranda Books, 1840-46, 1848-49. Michigan Historical Collections. Bentley Historical Library. Ann Arbor: University of Michigan. 


\section{Published Works:}

Adamson, Christopher. "God's Continent Divided: Politics and Religion in Upper Canada and The Northern and Western United States, 1775 to 1841." Comparative Studies in Society and History, 36, no. 3 (July 1994): 417-46.

Assikinack, Francis. "Legends and Traditions of the Odahwah Indians." The Canadian Journal of Industry, Science, and Art. New Series. July, 1858: 115-28.

. "Social and Warlike Customs of the Odahwah Indians." The Canadian Journal of Industry, Science, and Art. New Series. July 1858: 279-309.

"The Odahwah Indian Language." The Canadian Journal of Industry, Science, and Art. New Series. July 1858: 481-85.

Barker, Joanne. Native Acts: Law, Recognition, and Cultural Authenticity. Durham, NC: Duke University Press, 2011.

Belfy, Phil. Three Fires Unity: The Anishinaabeg of the Huron Borderlands. Lincoln: University of Nebraska Press, 2011.

Bissell, Mrs. Fanny. "Samuel Bissell and the Twinsburg Institute." In n.a. Twinsburg, Ohio, 1817-1917. Twinsburg, OH: Samuel Bissell Memorial Library Association of Twinsburg, 1917.

Blackbird, Andrew J. History of the Ottawa and Chippewa Indians of Michigan: A Grammar of Their Language and Personal and Family History of the Author. Ypsilanti, MI: The Ypsilantian Job Printing House, 1887 [reprint ed.: Little Traverse Regional History Society, Inc., n.d.]

Bleasdale, Ruth. "Manitowaning: An Experiment in Indian Settlement." Ontario History, LXVI (1974): 147-57.

Bohaker, Heidi. "'Nindoodemag': The Significance of Alonquian Kinship Networks in the Eastern Great Lakes Region, 1600-1701. William \& Mary Quarterly. 63, no. 1: 23-52.

Bowes, John P. Land Too Good for Indians: Northern Indian Removal. Norman: University of Oklahoma Press, 2016.

Brody, Hugh. Maps \& Dreams: Indians and the British Columbia Frontier. Prospect Heights, IL: Waveland Press, 1981.

Buss, James J. "Imagined World and Archival Realities: The Patchwork World of Early Nineteenth-Century Indiana.” In C. Joseph Genetin-Pilawa and James J. Buss, Beyond Two Worlds: Critical Conversations on Language and Power in Native North America. Albany: SUNY Press, 2014.

. Winning the West with Words: Language and Conquest in the Lower Great Lakes Norman: University of Oklahoma Press, 2011.

Carter, Sarah. Imperial Plots: Women, Land, and the Spadework of British Colonialism on the Canadian Prairie. Winnipeg: University of Manitoba Press, 2016.

Cherokee Nation v. State of Georgia. 30 U.S. 1 1831. caselaw.findlaw/US-supremecourt/30/1.html.

Cleland, Charles E. Faith in Paper: The Ethnohistory and Litigation of Upper Great Lakes Indian Treaties. Ann Arbor: University of Michigan Press, 2011.

. Rites of Conquest: The History and Culture of Michigan Native Americans. Ann Arbor: University of Michigan Press, 1992.

Cleland, James Hamilton. The Georgian Bay: An Account of Its Position, Inhabitants, Mineral Interests, Fish, Timber, and Other Resources with Map and Illustrations. Toronto: James Baird \& Son, 1893.

Clifton, James A., et al. People of the Three Fires: The Ottawa, Potawatomi, and Ojibway of Michigan. Grand Rapids: Michigan Indian Press, Grand Rapids Inter-Tribal Council, 1986. 
Corbiere, Alan. "Mookomaanish: The Damned Knife." In Alan Corbiere, Deborah McGregor, and Crystal Migwans, eds. Anishinaabewin Niswi: Deep Roots, New Growth. Proceedings of the 2012 Anishinaabewin Niswi Multidisciplinary Culture Conference. M'Chigeeng, ON: Ojibwe Cultural Foundation, 2013.

Corey Albert B. The Crisis of 1832-42 in Canadian-American Relations. New Haven: Yale University Press, 1941.

Coyle, Michael. "As Long as the Sun Shines: Recognizing That Treaties Were Intended to Last.” In Michael Coyle and John Borrows, eds. The Right Relationship: Reimagining the Implementation of Historical Treaties Toronto: University of Toronto Press, 2017.

Genetin-Pilawa, C. Joseph. Crooked Paths to Allotment: The Fight over Federal Indian Policy After the Civil War. Chapel Hill: University of North Carolina Press, 2012.

Harmon, Alexandra. Indians in the Making: Ethnic Relations and Indian Identities around Puget Sound. Berkeley: University of California Press, 1998.

Higham, C. L. Noble, Wretched \& Redeemable: Protestant Missionaries to the Indians in Canada and the United States, 1820-1900. Albuquerque: University of New Mexico Press, 2000.

Jagodinsky, Katrina. Legal Codes and Talking Trees: Indigenous Women's Sovereignty in the Sonoran and Puget Sound Borderlands, 1854-1946. New Haven: Yale University Press, 2016.

Jackson, Andrew. "State of the Union Address." December 6, 1830.

https:www.ourdocuments.gov/doc.php?doc=25\&page=transcript.

Jameson, Mrs. [Anna]. Winter Studies and Summer Rambles in Canada. Vol. II. New York: Wiley and Putnam, 1839.

Kappler, Charles J., ed. Indian Treaties, 1778-1883. Vol. II. Washington, DC: Government Printing Office, 1904.

Karamanski, Theodore J. Blackbird's Song: Andrew J. Blackbird and the Odawa People. East Lansing: Michigan State University Press, 2012.

King, Cecil. Balancing Two Worlds: Jean-Baptiste Assiginack and the Odawa Nation, 17681866. Saskatoon: Dr. Cecil King, 2013.

Landon, Fred. Western Ontario and the American Frontier. Toronto: Ryerson Press, 1941.

Leighton, Douglas. “Assiginack.” Dictionary of Canadian Biography. IX. 1976: 8-10. ."Assikinack." Dictionary of Canadian Biography. IX. 1976: 10-11.

MacLeod, D. Peter. "Microbes and Muskets: Small Pox and the Participation of Amerindian Allies of New France in the Seven Years' War," Ethnohistory, 39, no. 1 (Winter 1992): 42-64.

McClurken, James. Gah-Baeh-Jhagwuh-Buk The Way It Happened: A Visual Culture History of The Little Traverse Bay Bands of Ottawa. East Lansing: Michigan State University Museum, 1991.

."We Wish to Be Civilized': Ottawa-American Contests on the Michigan Frontier." East Lansing: Michigan State University Ph.D. diss., 1987.

McDonnell, Michael A. Masters of Empire: Great Lakes Indians and the Making of America. New York: Hill and Wang, 2015.

McManus, Sheila. The Line Which Separates: Race, Gender, and the Making of the AlbertaMontana Borderlands. Lincoln: University of Nebraska Press, 2005.

Miller, Cary. Ogimaag: Anishinaabeg Leadership, 1760-1845. Lincoln: University of Nebraska Press, 2010.

Nichols, Roger. Indians in the United States and Canada: A Comparative History. Lincoln: University of Nebraska Press, 1998.

Nicole St-Onge, Carolyn Podruchny, and Brenda Macdougall, eds. Contours of a People: 
Metis Family, Mobility, and History. Norman: University of Oklahoma Press, 2012.

Raibmon, Paige. Authentic Indians: Episodes of Encounter from the Late-Nineteenth-Century Northwest Coast. Durham, NC: Duke University Press, 2005.

Read, Colin. The Rising in Western Canada, 1837-8: The Duncombe Revolt and After. Toronto: University of Toronto Press, 1982.

Rogers, Edward S. "The Algonquian Farmers of Southern Ontario, 1830-1945," In Edward S. Rogers and Donald B. Smith, eds. Aboriginal Ontario: Historical Perspectives on the First Nations. Toronto: Ontario Historical Studies Series for the Government of Ontario, Dundurn Press, 1994.

Rosen, Deborah. American Indians and State Law: Sovereignty, Race, and Citizenship, 1790-1880. Lincoln: University of Nebraska Press, 2007.

Shea, John Gilmary. Catholic Missions among the Indian Tribes of the United States. New York: Arno Press \& The New York Times, 1969.

Smith, Donald B. Mississauga Portraits: Ojibwe Voices from Nineteenth-Century Canada. Toronto: University of Toronto Press, 2013.

Surtees, Robert J. "Land Cessions, 1763-1830." In Edward S. Rogers and Donald B. Smith. Aboriginal Ontario: Historical Perspectives on First Nations. Toronto: Dundurn Press, 1994.

. "The Development of an Indian Reserve Policy in Canada," Ontario History, 61, no. 2 (1969): 87-98.

Tanner, Helen Hornbeck, ed. Atlas of Great Lakes Indian History. Norman: University of Oklahoma Press, 1987.

Tanner, John. The Falcon: A Narrative of the Captivity \& Adventures of John Tanner during Thirty Years Residence among the Indians in the Interior of North America. New York: Penguin Books, 1994 [1830].

Taylor, J. Garth. "Assiginack's Canoe: Memories of Indian Warfare on the Great Lakes." The Beaver, 66, no. 5 (1986): 49-53.

Tucker, H.G. "A Warriors of the Odahwahs.” Ontario History. XVIII. 1920: 32-35.

Ward, Matthew C. "The Microbes of War: The British Army and Epidemic Disease among the Ohio Indians, 1758-1765." In David Curtis-Skaggs and Larry L. Nelson, eds. The Sixty Years' War for the Great Lakes, 1754-1814. East Lansing: Michigan State University Press, 2001.

Warren, Stephen. The Shawnees and Their Neighbors, 1795-1870. Urbana: University of Illinois Press, 2009.

White, Richard. The Middle Ground: Indians, Empires, and Republics in the Great Lakes Region, 1650-1815. Cambridge: Cambridge University Press, 2006 [1991].

Wilkins, David E. and K. Tsianina Lomawaima. Uneven Ground: American Indian Sovereignty and Federal Law. Norman: University of Oklahoma Press, 2001.

Wilton, Carol. Popular Politics and Political Culture in Upper Canada, 1800-1850. Montreal: McGill-Queens Press, 2000.

Witken, Michael. An Infinity of Nations: How the Native New World Shaped Early North America. Philadelphia: University of Pennsylvania Press, 2012. 